\title{
Upaya Meningkatkan Motivasi Belajar Bahasa Inggris Melalui Media Brosur Bimbingan Belajar dan Diskusi Kelompok pada Siswa SMP
}

\author{
Sarleni Rhepon \\ SMK Negeri 2 Kepahiang - Bengkulu \\ Email : lhenie_87@yahoo.com
}

\begin{abstract}
This study aims to increase the motivation to learn English through brochures tutoring and group discussions to junior high school students in orphanages orphaned daughter 'Aisyiyah. This research is action research (action research) with reference to the research design and Mc Taggart Kemmis. Subjects numbered nineteen people. Data collection instrument using a Likert scale of learning motivation, observation guidelines, and guidelines for the interview. Data analysis using t-test results showed that posttest Nineteen students are in good category, with a score percentage is between $76 \%-100 \%$. Based on the results of this study concluded that the media brochure tutoring and group discussions can increase motivation to learn English junior high school students in orphanages orphaned daughter `Aisyiyah. The results of this study can be used by counselors in helping students improve motivation to learn English through brochures tutoring and group discussions.
\end{abstract}

Keywords: motivation to learn, brochures, groups discussion

\begin{abstract}
Penelitian ini bertujuan untuk meningkatkan motivasi belajar bahasa Inggris melalui media brosur bimbingan belajar dan diskusi kelompok kepada siswa SMP di Panti asuhan yatim putri 'Aisyiyah. Penelitian ini adalah penelitian tindakan (action research) dengan desain penelitian mengacu pada Kemmis dan Mc Taggart. Subjek penelitian berjumlah sembilan belas orang. Instrumen pengumpulan data menggunakan skala Likert tentang motivasi belajar, pedoman observasi, dan pedoman wawancara. Analisis data menggunakan t-test Hasil posttest menunjukkan bahwa Sembilan belas siswa berada dalam ketegori baik, dengan skor persentase berada diantara 76\% - 100\%. Berdasarkan hasil penelitian dapat disimpulkan bahwa media brosur bimbingan belajar dan diskusi kelompok dapat meningkatkan motivasi belajar bahasa Inggris siswa SMP di panti asuhan yatim putri 'Aisyiyah. Hasil penelitian ini dapat digunakan oleh konselor dalam membantu siswa meningkatkan motivasi belajar bahasa Inggris melalui media brosur bimbingan belajar dan diskusi kelompok.
\end{abstract}

Kata kunci : motivasi belajar, media brosur, diskusi kelompok

\section{Pendahuluan}

Panti asuhan mengasuh siswa dari jenjang pendidikan di sekolah dasar hingga perguruan tinggi. Berbagai fasilitas yang ada di panti asuhan dapat dimanfaatkan untuk menunjang prestasi akademik siswa. Perhatian dari ibu pengasuh di panti asuhan turut membantu dalam mengontrol proses belajar mereka, sehingga siswa dapat mengembangkan kebiasaan belajar yang baik.

Syah (1995:132) menjelaskan ada tiga faktor yang mempengaruhi belajar siswa yaitu faktor internal seperti kesehatan jasmani, tingkat kecerdasan, sikap, bakat, minat, motivasi; dan faktor eksternal seperti sifat-sifat orang tua, praktik pengelolaan keluarga, gedung sekolah dan letaknya, alat-alat belajar; serta faktor pendekatan belajar seperti strategi yang digunakan siswa dalam proses pembelajaran. Oleh karena itu, penting bagi siswa motivasi dalam kegiatan belajarnya. Siswa yang memiliki motivasi belajar maka ia memiliki keinginan berhasil dalam belajar, adanya dorongan dan kebutuhan belajar, memiliki cita-cita, merasa senang belajar, dan tertarik untuk belajar (Uno, 2008:23). Oleh karena itu, perlu bagi siswa merasa senang belajar, giat belajar dan tekun mengerjakan tugastugas, mengulangi pelajaran sepulang sekolah dan berusaha memahami materi pelajaran yang ada di sekolah, agar tercapai prestasi akademik yang memuaskan.

Siswa yang senang belajar dapat menyesuaikan diri pada mata pelajaran yang bersifat menghafal, menghitung, maupun pada mata pelajaran yang menggunakan kemampuan verbal. Pelajaran bahasa Inggris merupakan salah satu pelajaran yang menggunakan kemampuan verbal, kemampuan menghafal, dan kemampuan menulis dalam menyusun kata yang benar. Siswa yang memiliki motivasi belajar tinggi pada mata pelajaran bahasa Inggris, maka akan tekun belajar pelajaran bahasa Inggris serta mampu mengerjakan pekerjaan rumah (PR). Menurut Untari ( 2013) keberhasilan dalam proses belajar 
mengajar dapat diukur dari keberhasilan siswa dalam mengikuti kegiatan pembelajaran yang dilaksanakan

Mengulang pelajaran di sekolah juga dapat dilakukan melalui diskusi kelompok. Pada saat diskusi kelompok, siswa yang telah memahami materi pelajaran sekolah dapat membantu menjelaskan kembali materi tersebut pada teman kelompoknya yang belum memahami materi pelajaran tersebut, dan seluruh anggota kelompok dapat berdialog membahas materi pelajarannya. Adanya, diskusi kelompok akan membantu mengatasi kesulitan belajar anggota kelompok, dan juga dapat saling memberikan semangat belajar.

Salah satu upaya mengarahkan siswa agar semangat belajar yaitu dengan melaksanakan layanan bimbingan belajar. Yusuf \& Nurihsan (2006:10) mengemukakan layanan bimbingan belajar diarahkan untuk membantu siswa dalam menghadapi dan memecahkan masalah-masalah belajar. Seperti, masalah pengenalan kurikulum, pemilihan jurusan, cara belajar, penyelesaian tugas-tugas dan latihan, pencarian dan penggunaan sumber belajar, perencanaan pendidikan lanjutan, dan lain-lain. Oleh karena itu, siswa dapat menemukan cara belajar yang tepat sesuai dengan keadaan dirinya, meningkatkan motivasi belajar, meningkatkan keterampilan belajar serta pengembangan sikap untuk menimbulkan kebiasaan belajar yang baik.

Layanan bimbingan bersifat informative kepada siswa (Sukmadinata, 2005:243). Layanan tersebut dapat diberikan secara langsung seperti di dalam kelas atau tatap muka, maupun secara tidak langsung melalui suatu media berbentuk brosur, tulisan dalam majalah sekolah, tulisan pada papan bimbingan, dan lain sebagainya.

Layanan bimbingan belajar melalui media brosur yang diberikan pada siswa terbilang cukup efektif. Materi pada brosur bimbingan belajar disusun menarik, dengan tulisan yang berwarnawarni, penekanan teks yang penting dengan huruf dicetak tebal atau dicetak miring, dan memanfaatkan gambar-gambar yang disesuaikan dengan materi. Oleh karena itu, informasi yang disusun dalam brosur bimbingan belajar dapat dibaca dan dipahami oleh siswa secara mandiri. Sehingga, siswa dapat mengembangkan kebiasaan belajar yang baik, bahkan dapat meningkatkan minat dan motivasi belajarnya.

Dalam kenyataan, kurangnya motivasi belajar masih menjadi salah satu faktor penghambat keberhasilan belajar siswa. Beberapa siswa masih memiliki rasa malas belajar, malas mengulang pelajaran dari sekolah, dan malas membaca buku pelajaran. Sehingga, tidak sedikit siswa memperoleh hasil nilai ujiannya tergolong rendah, karena ketidakseriusan siswa dalam kegiatan belajarnya. Hal tersebut juga dirasakan pada siswa SMP di panti asuhan yatim putri 'Aisyiyah Yogyakarta.

Hasil wawancara pada beberapa anak asuh pada tingkat SMP, mengatakan bahwa mereka sering merasa malas belajar, sering menundanunda kegiatan belajarnya, dan akan belajar lebih serius jika akan ada ujian. Menurut ibu pengasuh, sebagian anak asuh SMP jika memiliki waktu luang maka tidak dimanfaatkan untuk mengulang pelajaran sekolah atau mempelajari pelajaran berikutnya. Sebagian, anak asuh menggunakan waktu luang dengan hal-hal yang kurang mendukung kegiatan belajar, seperti membaca buku cerita, mengobrol, dan lain-lain. selanjutnya, ibu pengasuh juga mengatakan

Anak asuh juga mengalami kesulitan belajar pada mata pelajaran tertentu di sekolahnya. Dari hasil wawancara pada beberapa anak asuh, diketahui bahwa mereka kurang menyukai pelajaran bahasa Inggris di sekolahnya. Menurut sebagian anak asuh, pelajaran bahasa Inggris tersebut memiliki kosa kata yang sulit dihafal dan susunan kalimat yang sulit dibaca, sehingga mereka menganggap pelajaran bahasa Inggris sulit dimengerti. Keterangan tersebut juga didukung oleh pendapat ibu pengasuh bahwa sebagian anak asuh menganggap pelajaran bahasa Inggris di sekolah tergolong sulit sehingga anak asuh tersebut kurang berminat mempelajari pelajaran bahasa Inggris.

Sebagai solusi untuk membantu hambatan belajar anak asuh, maka pihak panti mendatangkan relawan sebagai pengajar di panti asuhan. Pengajar tersebut berasal dari mahasiswa mengajar pelajaran sekolah termasuk pelajaran bahasa Inggris. Ibu pengasuh mengatakan jika anak asuh belajar bersama pengajar panti, mereka kurang aktif bertanya atau menyampaikan pendapat karena malu bertanya, sehingga mereka tetap kurang mengerti pelajaran bahasa Inggris.

Hasil wawancara dengan ibu pengasuh bahwa nilai pelajaran bahasa Inggris sebagian anak asuh SMP kurang memuaskan dibandingkan dengan nilai pelajaran lainnya (misalnya biologi). Beberapa anak asuh mengatakan jika mereka mendapat PR dari guru bahasa Inggris di sekolah, maka beberapa mereka akan mengerjakan PR tersebut semampunya saja, dan sisa pertanyaan yang belum dijawab akan dijawab dengan menyalin pekerjaan teman di kelasnya.

Beberapa anak asuh mengatakan bahwa guru bimbingan dan konseling di sekolah belum memanfaatkan layanan bimbingan belajar dalam bentuk brosur bimbingan belajar. Padahal anak asuh tertarik untuk membaca materi yang ada pada brosur tentang pengenalan suatu sekolah atau universitas. Beberapa anak asuh mengatakan bahwa mereka suka membaca terutama buku 
bacaan yang sifatnya ringan di baca misalnya novel atau komik. Jika ada waktu luang, anak asuh SMP meminjam buku bacaan di perpustakaan panti. Hasil observasi, di panti asuhan tersebut belum ada yang memanfaatkan media brosur sebagai upaya membantu mengatasi hambatan belajar anak asuh. Beberapa anak asuh SMP juga mengatakan bahwa mereka belum pernah mempelajari pelajaran bahasa Inggris secara berkelompok bersama teman sebaya di panti.

Melihat fenomena tersebut, perlu alternatif pemecahan masalah untuk membantu anak asuh mengatasi hambatan belajarnya. Mengingat perlunya kemampuan dalam berbahasa Inggris, misalnya untuk kelulusan sekolah SMP, untuk melanjutkan pendidikan ke sekolah favorit, atau untuk meraih pekerjaan yang diminati di masa yang akan datang. Oleh karena itu, motivasi belajar pada mata pelajaran bahasa Inggris khususnya untuk anak asuh SMP di panti asuhan perlu ditingkatkan. Peningkatan motivasi belajar pelajaran bahasa Inggris tersebut agar anak asuh SMP di panti kelak dapat memanfaatkan kemampuan bahasa Inggrisnya untuk mencapai cita-citanya.

Salah satu upaya untuk meningkatkan motivasi belajar pelajaran bahasa Inggris bagi anak asuh, yaitu dengan cara memberikan layanan bimbingan belajar. Pemberian layanan bimbingan belajar tersebut melalui pemberian media brosur bimbingan belajar dan melaksanakan diskusi kelompok. Brosur bimbingan belajar tersebut berisi materi-materi bimbingan belajar dalam bentuk cetak yang menarik, misalnya materi tentang cara belajar bahasa Inggris yang efektif, kiat mudah belajar bahasa Inggris, dan lain-lain. Brosur yang telah diberikan pada anak asuh nantinya akan dibahas saat diskusi kelompok. Pelaksanaan diskusi kelompok tersebut bertujuan agar anak asuh dapat berdialog dan berinteraksi antar anggota kelompok untuk membahas materi bimbingan belajar yang telah diberikan.

Secara operasional, penelitian ini bertujuan untuk meningkatkan motivasi belajar bahasa Inggris melalui media brosur bimbingan belajar dan diskusi kelompok kepada siswa SMP di Panti asuhan yatim putri 'Aisyiyah. Hasil penelitian ini dapat digunakan oleh konselor dalam membantu siswa meningkatkan motivasi belajar bahasa Inggris melalui media brosur bimbingan belajar dan diskusi kelompok.

\section{Kajian Literatur}

\section{Motivasi Belajar Pelajaran Bahasa Inggris}

Motivasi belajar sangat diperlukan dalam aktivitas belajar. Banyak para ahli yang telah mengemukakan pengertian motivasi belajar. Winkel \& Hastuti (2004:169) menyatakan bahwa "motivasi belajar ialah keseluruhan daya penggerak psikis dalam diri siswa yang menimbulkan kegiatan belajar, menjamin kelangsungan kegiatan belajar dan memberikan arah pada kegiatan belajar demi mencapai suatu tujuan.” Selanjutnya, Dimyati \& Mudjiono (2006:239) mengemukakan "motivasi belajar merupakan kekuatan mental yang mendorong terjadinya proses belajar”. Berikutnya, Yamin (2007:219) juga mengemukakan motivasi belajar merupakan daya penggerak psikis dari dalam diri seseorang untuk dapat melakukan kegiatan belajar, menambah keterampilan dan pengalaman.

Berdasarkan penjelasan di atas, maka dapat disimpulkan bahwa motivasi belajar adalah suatu penggerak psikis yang ada dalam diri siswa yang dapat menimbulkan aktivitas belajar, menjamin kelangsungan aktivitas belajar, serta mengarahkan aktivitas belajarnya kepada tujuan belajarnya. Djamarah (2008:157) telah merumuskan beberapa fungsi motivasi dalam belajar, antara lain Motivasi sebagai pendorong perbuatan. pada mulanya siswa tidak ada hasrat untuk belajar, tetapi karena ada sesuatu yang dicari muncullah minatnya untuk belajar. Hal ini dalam rangka untuk memuaskan rasa ingin tahunya dari sesuatu yang akan dipelajari. Sesuatu yang belum diketahui itu akhirnya mendorong siswa untuk belajar dalam rangka mencari tahu. Siswa pun mengambil sikap seiring dengan minat terhadap suatu objek. Sikap itulah yang mendasari dan mendorong ke arah sejumlah perbuatan dalam belajar. Motivasi sebagai penggerak perbuatan, Dorongan psikologis yang melahirkan sikap terhadap siswa merupakan suatu kekuatan yang tak terbendung, yang kemudian terjelma dalam bentuk gerakan psikofisik. Di sini siswa sudah melakukan aktivitas belajar dengan segenap jiwa dan raga. Sikap berada dalam kepastian perbuatan dan akal pikiran mencoba membedah nilai yang terpatri dalam wacana, prinsip, dalil, dan hukum, sehingga mengerti betul isi yang dikandungnya.

Motivasi sebagai pengarah perbuatan, Siswa yang memiliki motivasi dapat menyeleksi perbuatan yang harus dilakukan dan yang diabaikan. Siswa yang ingin mendapatkan sesuatu dari suatu mata pelajaran tertentu, tidak mungkin dipaksakan untuk mempelajari mata pelajaran yang lain. Siswa akan mempelajari mata pelajaran di mana tersimpan sesuatu yang akan dicari sebagai tujuan belajarnya. Tujuan belajar itulah sebagai pengarah yang memberikan motivasi dalam belajar. Dengan tekun siswa akan belajar agar tujuannya mencari sesuatu yang ingin diketahui/dimengerti itu cepat tercapai. Motivasi sangat berpengaruh terhadap proses kegiatan belajar siswa. Sukmadinata (2007:387) 
mengemukakan motivasi belajar memegang peranan yang sangat penting, mempengaruhi aktivitas, kesungguhan, dan akhirnya menentukan hasil belajar siswa. Sehingga, siswa akan bersungguh-sungguh, tekun, dan rajin belajar. Sebaliknya, jika siswa kurang memiliki motivasi belajar maka akan menunjukkan gejala-gejala: kemalasan, keengganan, apatisme, bekerja asalan, mudah menyerah, putus asa dan sebagainya. Selanjutnya, Sardiman (2006:83) mengemukakan adapun ciri-ciri siswa yang memiliki motivasi dalam belajar, antara lain tekun menghadapi tugas, ulet menghadapi kesulitan, menunjukkan minat terhadap bermacam-macam masalah, lebih senang bekerja mandiri, cepat bosan pada tugas yang rutin, dapat mempertahankan pendapatnya. tidak mudah melepaskan hal-hal yang diyakini, senang mencari dan memecahkan masalah pembelajaran.

Apabila siswa memiliki ciri-ciri tersebut, berarti ia selalu memiliki motivasi belajar yang cukup kuat. Ciri-ciri motivasi seperti itu akan sangat penting dalam pembelajaran. Motivasi belajar pelajaran bahasa Inggris ialah suatu penggerak psikis yang ada dalam diri individu yang menimbulkan aktivitas belajar pelajaran bahasa Inggris, menjamin kelangsungan aktivitas belajarnya, serta mengarahkan aktivitas belajarnya kepada tujuan belajarnya. Motivasi belajar bahasa Inggris juga dapat timbul dari dalam diri individu (intrinsik) maupun dari luar diri (ekstrinsik). Faktor intrinsik ini berupa hasrat dan keinginan untuk berhasil dari kegiatan belajarnya, serta adanya dorongan untuk butuh belajar. Sedangkan faktor ekstrinsik berupa keinginan mendapat penghargaan, adanya lingkungan belajar yang kondusif, kegiatan belajar yang menarik.

\section{Brosur Bimbingan Belajar}

Layanan bimbingan dapat diberikan secara langsung maupun tidak langsung, sesuai dengan yang dikemukakan oleh Winkel \& Hastuti (2004:111) yaitu: Bimbingan langsung berarti pelayanan bimbingan yang diberikan kepada siswa oleh tenaga bimbingan sendiri, dalam suatu pertemuan tatap muka dengan satu siswa atau sejumlah siswa. Bimbingan tidak langsung berarti pelayanan bimbingan yang diberikan oleh tenaga bimbingan melalui tenaga pendidik yang lain, misalnya seorang guru yang telah berkonsultasi dengan konselor sekolah tentang siswa tertentu dan kemudian berhubungan lagi dengan siswa itu; atau pelayanan yang diberikan oleh tenaga bimbingan melalui suatu medium, misalnya dalam brosur, pamflet, tulisan dalam majalah sekolah, tulisan pada papan bimbingan, dan lain sebagainya.
Bimbingan belajar juga dapat diberikan secara langsung oleh pembimbing secara tatap muka atau pemberian bimbingan belajar secara tidak langsung dengan memanfaatkan suatu media bimbingan. Media yang dipilih dalam penelitian ini yaitu brosur bimbingan belajar. Menurut Arsyad (2002:37) brosur sebagai media cetakan ialah pengumuman atau pemberitahuan mengenai sesuatu program atau pelayanan. Selanjutnya, Kamus Besar Bahasa Indonesia (2002) mengemukakan "brosur ialah 1. Bahan informasi tertulis mengenai suatu masalah yang disusun secara bersistem; 2. Cetakan yang hanya terdiri atas beberapa halaman dan dilipat tanpa dijilid; 3 . Selebaran cetakan yang berisi keterangan singkat tetapi lengkap.”

Berdasarkan penjelasan tersebut, maka media brosur ialah suatu alat untuk menyampaikan informasi yang sistematis yang dicetak pada beberapa halaman kertas dan dilipat. Oleh karena itu, media brosur bimbingan belajar merupakan suatu alat untuk menyampaikan informasi yang diberikan kepada siswa dalam menghadapi dan memecahkan masalah belajarnya.

Penyusunan brosur perlu diperhatikan susunan kalimat dalam teks, agar siswa yang pembaca tidak bingung dalam memahami materi yang disusun. Materi dalam brosur ditulis dengan bahasa yang ringkas dan mudah dipahami. Brosur juga didesain agar menarik perhatian, dan dicetak di atas kertas yang baik dalam usaha membangun citra yang baik terhadap layanan atau produk tersebut.

Brosur bimbingan belajar berisi berbagai materi tentang pemecahan masalah belajar siswa. Adapun materi yang disampaikan dalam materi brosur bimbingan belajar, antara lain informasi mengenai gaya belajar yang baik sesuai dengan keadaan dirinya, informasi mengenai cara belajar yang efektif dan efisien, informasi mengenai teknik menguasai materi pelajaran.

\section{Diskusi Kelompok}

Sukardi (2008:220) mengemukakan bahwa “diskusi kelompok ialah suatu pertemuan dua orang atau lebih, yang ditujukan untuk saling tukar pengalaman dan pendapat, dan biasanya menghasilkan suatu keputusan bersama”. Pelaksanaan diskusi kelompok memiliki beberapa keuntungan bagi siswa, yaitu seperti yang telah dikemukakan oleh Suryosubroto (2002:185) antara lain melibatkan semua siswa secara langsung dalam proses belajar, setiap siswa dapat menguji tingkat pengetahuan dan penguasaan bahan pelajarannya masing-masing, menumbuhkan dan mengembangkan cara berpikir dan sikap ilmiah, dengan mengajukan dan mempertahankan pendapatnya dalam diskusi diharapkan para siswa akan dapat memperoleh 
kepercayaan akan (kemampuan) diri sendiri, dan menunjang usaha-usaha pengembangan sikap sosial dan demokratis para siswa.

\section{Metode Penelitian}

Penelitian ini menggunakan penelitian tindakan (action research). Desain penelitian mengacu pada Kemmis dan Mc Taggart, meliputi perencanaan, pelaksanaan (acting) dan pengamatan (observing), refleksi (Arikunto, 2005:93).

Perencanaan dimaksudkan bahwa tindakan yang akan dilakukan harus memandang ke depan. Selanjutnya, pelaksanaan tindakan adalah pelaksanaan yang merupakan implementasi atau penerapan isi rencana yang dibuat (Arikunto, 2006:18). Berikutnya, observasi yang dilakukan untuk mengetahui kesesuaian pelaksanaan tindakan dengan rencana tindakan, dan untuk mengetahui motivasi belajar pelajaran bahasa Inggris siswa setelah diberikan tindakan. Terakhir, refleksi dilakukan untuk memahami proses dan mengetahui sejauh mana pengaruh pemberian brosur bimbingan belajar dan diskusi kelompok dalam meningkatkan motivasi belajar pelajaran bahasa Inggris siswa, serta kendala yang terjadi selama proses pemberian tindakan berlangsung. Refleksi diperoleh dari hasil wawancara pada subjek penelitian dan hasil observasi pelaksanaan diskusi kelompok.

Peneliti mengangkat masalah pembelajaran siswa yang akan dipecahkan, dengan memperbaiki proses pembelajaran dengan suatu tindakan. Penelitian ini bertujuan meningkatkan motivasi belajar pelajaran bahasa Inggris bagi siswa SMP di panti asuhan yatim putri 'Aisyiyah Yogyakarta. Peneliti berkerja sama dengan salah seorang musrifah yang ada panti asuhan dalam pelaksanaan tindakan. Musrifah tersebut ialah seorang anak panti asuhan yang mengenyam pendidikan di perguruan tinggi, yang dipercaya untuk membimbing adik tingkatnya yang tinggal di panti asuhan tersebut.

Subjek penelitian dalam penelitian ini adalah siswa SMP di panti asuhan yatim putri 'Aisyiyah Yogyakarta berjumlah 19 orang. Pemilihan subjek penelitian melalui teknik populasi, yaitu teknik pemilihan subjek yang didasarkan pada kualitas dan karakteristik tertentu yang ditetapkan oleh peneliti untuk dipelajari dan kemudian ditarik kesimpulan (Sugiyono, 2009:89).

Pengumpulan data menggunakan instrumen skala model Likert tentang motivasi belajar, wawancara, dan observasi. Validasi instrumen yang digunakan yaitu logical validity (validitas logik) karena validitasnya berdasarkan pada konstruksi teoritik yang diukur. Uji validitas instrumen ini menggunakan program komputer
SPSS 12. Instrumen penelitian tersebut diuji coba kepada 34 responden. pernyataan-pernyataan yang diikutkan dalam skala motivasi belajar adalah yang memiliki koefisien korelasi tidak kurang dari 0,30. Item skala motivasi belajar yang akan digunakan yaitu item yang sahih berjumlah 33 item. Setelah diuji reliabilitas dengan teknik Alpha Cronbach menggunakan program komputer SPSS 12, instrumen memiliki koefisien 0,684 . Hal ini menunjukkan bahwa instrumen motivasi belajar memiliki reliabilitas tinggi.

Data dianalisis melalui analisis deskriptif kuantitatif dan deskriptif kualitatif. Analisis deskriptif kuantitatif memanfaatkan teknik persentase, dan analisis deskriptif kualitatif yaitu persentase yang dinyatakan dalam bilangan diubah menjadi sebuah predikat misalnya baik, cukup, kurang, tidak baik. Adapun data kualitatif dalam penelitian ini adalah data hasil observasi, wawancara. Hasil nilai pre test dengan post test yang diperoleh dari subjek penelitian akan dibandingkan untuk mengetahui adanya peningkatan motivasi belajar pelajaran bahasa Inggris pada siswa SMP di Panti Asuhan Yatim Putri ‘Aisyiyah Yogyakarta.

\section{Hasil Penelitian dan Pembahasan}

Adapun hasil pelaksanaan tindakan meliputi pra tindakan, siklus I, dan siklus II. Adapun penjelasannya sebagai berikut.

Pra Tindakan

Pemberian pre test motivasi belajar pada subjek penelitian. Adapun rangkuman hasil pre test sebagaimana Tabel 1

Tabel 1.

Rangkuman Hasil Pre test

\begin{tabular}{ccccc}
\hline Kategori & Skor & Nama Inisial & $\begin{array}{c}\text { Jumlah } \\
\text { Siswa }\end{array}$ & (\%) \\
\hline Baik & $\begin{array}{c}76 \%- \\
100 \%\end{array}$ & $\begin{array}{c}\text { Bq, En, Mf, } \\
\text { Ms, Ri, St. } \\
\text { Bl, Bt, Dw, Dn, } \\
\text { Hf, Is, Ng, Ri, } \\
\text { Rs, Sr, Tl, Tn, } \\
\text { Um }\end{array}$ & 13 & 31,58 \\
Cukup & $56 \%-75 \%, 42$ \\
$\begin{array}{c}\text { Kurang } \\
\text { Baik } \\
\text { Tidak } \\
\text { Baik }\end{array}$ & $40 \%-55 \%$ & - & 0 & 0 \\
\hline
\end{tabular}

Berdasarkan data tersebut dapat diketahui bahwa sebelum diberi tindakan, rata-rata motivasi belajar pada mata pelajaran bahasa Inggris siswa di panti asuhan berada dalam kategori cukup. Selanjutnya, peneliti membagi siswa menjadi dua kelompok berjumlah 9 atau 10 orang setiap kelompoknya. Pembagian kelompok diserahkan pada siswa dibantu oleh peneliti dan Musrifah panti. Berikutnya, peneliti memberikan brosur 


\section{MOTIVASI BELAJAR, BROSUR, DISKUSI KELOMPOK}

bimbingan belajar kepada siswa. Mereka diminta untuk membaca dan memahami isi materi tersebut, dan pada pertemuan yang akan datang materi tersebut akan dibahas dalam diskusi kelompok.

Siklus I

Pada siklus I, peneliti melakukan perencanaan, pelaksanaan tindakan I, observasi, refleksi, dan melaksanakan post test I. Peneliti menjelaskan tentang bentuk diskusi kelompok yang akan dilaksanakan, yaitu membahas materi-materi brosur bimbingan belajar dan meminta siswa ikut aktif dalam kegiatan tersebut, pada siklus ini akan dibagikan 2 buah brosur bimbingan belajar, pemberian materi brosur bimbingan belajar secara berkala, masing-masing dibahas satu kali pertemuan saat diskusi kelompok berlangsung, pelaksanaan diskusi kelompok I dengan Brosur bimbingan belajar I berjudul : Cara Mengikuti Pelajaran Bahasa Inggris Di Kelas. Adapun kegiatan yang dilaksanakan yaitu : peneliti memulai kegiatan diskusi kelompok dengan berdo'a. Setelah itu, peneliti sebagai pembahas materi menyampaikan tujuan dan manfaat dari pelaksanaan diskusi kelompok, peneliti membahas materi brosur bimbingan belajar yang telah diberikan. Siswa diberi kesempatan untuk ikut berpartisipasi. Apabila ada yang belum dimengerti, maka peneliti memberi kesempatan kepada siswa lain untuk menjawab pertanyaan dari temannya, selanjutnya, peneliti memberi pertanyaan agar siswa dapat berdiskusi bersama teman kelompoknya. Pertanyaannya yaitu bagaimana persiapan siswa sebelum belajar pelajaran bahasa Inggris dikelas, dan apa saja yang dilakukan ketika mengikuti pelajaran bahasa Inggris di kelas. Jawaban dari pertanyaan tersebut dapat ditulis pada kertas yang telah disediakan. Peneliti bersama Musrifah panti mengamati jalannya diskusi kelompok.

Berikutnya, siswa dapat menyampaikan hasil diskusi mereka. Peneliti menyimpulkan hasil dari diskusi kelompok yang telah berlangsung. Peneliti memberikan penguatan kepada siswa untuk menerapkan tips mengikuti pelajaran bahasa Inggris di kelas yang telah dibahas. Peneliti mengakhiri kegiatan diskusi kelompok dengan meminta siswa untuk melafazkan hamdallah, dan membagikan brosur ke dua untuk dibaca dan akan didiskusikan pada waktu berikutnya.

Pelaksanaan diskusi kelompok II dengan Brosur bimbingan belajar I berjudul: Menghafalkan Kosa Kata Bahasa Inggris Sesuai Dengan Gaya Belajarmu. Adapun kegiatan yang dilaksanakan yaitu peneliti memulai kegiatan diskusi kelompok dengan berdo’a. Setelah itu, peneliti sebagai pembahas materi menyampaikan tujuan dan manfaat dari pelaksanaan diskusi kelompok, peneliti membahas materi pada brosur bimbingan belajar tersebut, dan memberi kesempatan pada peserta untuk bertanya jika ada yang kurang dimengerti tentang materi dalam brosur, peneliti meminta masing-masing kelompok untuk memikirkan gaya belajarnya dan meminta mereka untuk menjawab pertanyaan yaitu apa gaya belajarmu dan bagaimana anda dapat menghafalkan kosa kata bahasa Inggris sesuai dengan gaya belajarmu, pertanyaan tersebut dijawab secara berdiskusi bersama teman kelompoknya. Hasil diskusi ditulis dalam kertas yang telah disediakan, siswa menyampaikan hasil diskusi kelompok. Selanjutnya, peneliti menarik kesimpulan berdasarkan kegiatan diskusi kelompok tersebut, peneliti mengakhiri kegiatan diskusi kelompok dengan meminta siswa untuk melafazkan hamdallah.

Hasil observasi dari pelaksanaan tindakan yaitu pelaksanaan diskusi kelompok I dapat berjalan. Seluruh siswa mendengarkan penjelasan tentang bahasan materi brosur, tampak siswa malu-malu dalam mengungkapkan pendapat, dan siswa belum berani bertanya, pelaksanaan diskusi kelompok II berjalan lancar. Seluruh peserta mendengarkan penjelasan tentang materi yang dibahas, siswa telah dapat mengemukakan pendapatnya, dan beberapa siswa telah berani bertanya. Hasil refleksi yaitu berdasarkan pengamatan yang dilakukan peneliti bersama Musrifah Panti, tampak seluruh siswa memperhatikan penjelasan materi, berpartisipasi dalam mengerjakannya tugas kelompok, namun seluruh siswa belum mampu mengemukakan pendapatnya.

Berdasarkan wawancara, diketahui bahwa siswa memahami materi brosur bimbingan belajar yang diberikan. Tulisan dalam brosur yang warna-warni membuat siswa tertarik membacanya. Beberapa siswa mengusulkan untuk lebih banyak memberikan gambar-gambar pada brosur agar brosur tersebut lebih baik lagi.

Peneliti melakukan post test I setelah pemberian tindakan. Hasil post test $I$ tersebut yaitu 12 orang siswa yang berada dalam kategori baik diantaranya Bq, Bl, Dw, Dn, En, Hf, Mf, Ms, $\mathrm{Ri}, \mathrm{Sr}, \mathrm{St}, \mathrm{Tl}$. Kemudian 7 orang siswa lainnya masih berada dalam kategori cukup, yaitu Bt, Is, $\mathrm{Ng}, \mathrm{Rn}, \mathrm{Rs}, \mathrm{Tn}, \mathrm{Um}$. Secara keseluruhan, target penelitian belum tercapai karena motivasi belajar pelajaran bahasa Inggris siswa belum berada dalam kategori baik, sehingga perlu diadakan tindakan kembali yang diberikan dalam siklus II.

Siklus II

Pada siklus II, peneliti melakukan perencanaan, pelaksanaan tindakan II, observasi, refleksi, dan melaksanakan post test. Adapun rincian kegiatannya pada siklus ini akan 
dibagikan 2 buah brosur bimbingan belajar yang dibuat lebih menarik dengan memberikan gambar lebih banyak, pemberian materi brosur bimbingan belajar secara berkala, masing-masing dibahas satu kali pertemuan saat diskusi kelompok berlangsung, pelaksanaan diskusi kelompok I dengan Brosur bimbingan belajar I berjudul : Tips Asyik Belajar Bahasa Inggris. Adapun kegiatan yang dilaksanakan yaitu peneliti memulai kegiatan diskusi kelompok dengan berdo’a. Setelah itu, peneliti sebagai pembahas materi menyampaikan tujuan dan manfaat dari pelaksanaan diskusi kelompok, peneliti membahas materi dalam brosur tersebut dan memberikan kesempatan pada siswa untuk menyampaikan pertanyaan. peneliti memberikan pertanyaan pada siswa untuk mendiskusikan jawabannya bersama rekan kelompoknya, pertanyaannya yaitu apakah tujuan anda mempelajari pelajaran bahasa Inggris dalam jangka pendek dan panjang, dan bagaimanakah cara anda agar anda tertarik mempelajari pelajaran bahasa Inggris. Hasil diskusi ditulis pada kertas yang disediakan.

Siswa mempresentasikan hasil diskusi. Selanjutnya, peneliti mengajak siswa untuk menarik kesimpulan berdasarkan materi yang dibahas. Peneliti mengakhiri kegiatan diskusi kelompok dan membagikan brosur bimbingan belajar yang kedua untuk dibaca dan akan didiskusikan pada pertemuan berikutnya.

Pelaksanaan diskusi kelompok II dengan Brosur bimbingan belajar II berjudul: Asyiknya Belajar Bahasa Inggris Dengan Catatan Rapi. Adapun kegiatan yang dilaksanakan yaitu peneliti memulai kegiatan diskusi kelompok dengan berdo'a. Setelah itu, peneliti sebagai pembahas materi menyampaikan tujuan dan manfaat dari pelaksanaan diskusi kelompok, peneliti menjelaskan materi tersebut dan memberikan kesempatan untuk bertanya jika ada materi yang kurang dimengerti, peneliti memberikan pertanyaan yang akan didiskusikan siswa bersama teman kelompoknya, pertanyaannya yaitu bagaimana anda membuat catatan pelajaran bahasa Inggris yang rapi agar tertarik untuk membaca catatan tersebut. Hasil diskusi ditulis dalam kertas yang telah disediakan, siswa mempresentasikan hasil diskusi kelompoknya. Selanjutnya, peneliti mengajak siswa menarik kesimpulan dari kegiatan diskusi tersebut. Selain itu peneliti meminta pada siswa untuk menerapkan hasil diskusi mereka serta menerapkan tips-tips yang telah diberikan dalam bentuk brosur bimbingan belajar agar mereka menjadi semangat belajar pelajaran bahasa Inggris.

Hasil observasi dari pelaksanaan tindakan yaitu pelaksanaan diskusi kelompok I berjalan lancar, karena siswa sudah mulai aktif bertanya mengenai materi yang belum dimengerti. Mereka juga antusias untuk mengerjakan pertanyaan kelompok, pelaksanaan diskusi kelompok II berjalan lancar, karena siswa mau mengerjakan pertanyaan kelompok. Selain itu, terdapat beberapa siswa yang bertanya mengenai materi dalam brosur bimbingan belajar dan dapat dijawab oleh siswa lain.

Hasil refleksi yaitu hasil dari pelaksanaan diskusi kelompok yaitu siswa menjadi paham mengenai tujuan mempelajari pelajaran bahasa Inggris, dan apa saja yang membuat mereka tertarik belajar bahasa Inggris, serta siswa juga mengerti bagaimana cara membuat catatan pelajaran bahasa Inggris yang rapi sehingga mudah untuk dibaca., hasil wawancara, siswa merasakan manfaat mengikuti kegiatan diskusi kelompok tersebut karena memperoleh pengetahuan mengenai cara belajar bahasa Inggris yang sebelumnya belum mereka ketahui. Selain itu siswa dapat belajar mengungkapkan pendapatnya. Siswa lebih tertarik membaca brosur bimbingan belajar yang diberikan karena terdapat gambar yang menarik.

Hasil yang diperoleh subjek penelitian menunjukkan kemampuan akhir yang baik dibandingkan dengan kemamuan awal sebelum diberi tindakan. Hal ini menunjukkan bahwa motivasi belajar pelajaran bahasa Inggris siswa telah mengalami peningkatan, sehingga peneliti menghentikan pemberian tindakan karena telah mencapai target penelitian yaitu motivasi belajar pelajaran bahasa Inggris siswa berada dalam kategori baik.

Motivasi belajar sangat diperlukan dalam kegiatan belajar, agar siswa dapat menjalankan aktivitas belajar. Hal ini seperti yang telah dikemukakan oleh Djamarah (2008:148) bahwa motivasi sangat diperlukan karena seseorang yang tidak mempunyai motivasi dalam belajar, tak akan mungkin melakukan aktivitas belajar. Selain itu Robertus Angkowo dan Kosasih (2007:36) mengemukakan seseorang melalukan suatu usaha karena ada motivasi. Adanya motivasi yang kuat dalam belajar akan menunjukkan hasil yang baik, sehingga semakin tinggi motivasi belajar seseorang maka hasil belajarnya akan baik pula.

Tindakan yang diberikan dalam penelitian ini yaitu pemberian brosur bimbingan belajar dan pengadaan diskusi kelompok. Siswa yang telah menerima brosur bimbingan belajar, akan membahas materi tersebut dalam kegiatan diskusi kelompok. Berbagai materi dalam brosur bimbingan belajar berisi tentang materi layanan bimbingan belajar.

Brosur bimbingan belajar disusun sedemikian rupa dengan materi tidak terlalu panjang agar 


\section{MOTIVASI BELAJAR, BROSUR, DISKUSI KELOMPOK}

siswa tidak bosan membacanya. Arsyad (2002:88) mengemukakan pedoman menyusun brosur bimbingan belajar yaitu warna yang digunakan sebagai alat penuntun dan penarik perhatian kepada informasi yang penting, selain itu dapat menggunakan penekanan kata-kata kunci atau judul dengan huruf dicetak tebal atau dicetak miring, atau informasi yang penting diberi penekanan dengan menggunakan kotak. Penggunaan garis bawah sebagai alat penuntun sedapat mungkin dihindari karena membuat kata itu sulit dibaca. Selain itu, Arsyad (2002:37) mengemukakan lembaran pada brosur dapat berisi gambar atau foto di samping teks materi.

Pelaksanaan diskusi kelompok merupakan pertemuan dua orang atau lebih untuk saling bertukar pendapat dan bertukar pengalaman, dan biasanya menghasilkan suatu keputusan. Pelaksanaan diskusi kelompok tersebut dimaksudkan memberi kesempatan kepada siswa untuk memahami lebih jauh materi-materi yang ada dalam brosur bimbingan belajar yang telah diberikan. Pada saat diskusi kelompok berlangsung siswa mendapatkan kesempatan bertanya dan menyampaikan pendapatnya dengan konsekuensi siswa harus mendengarkan penyaji materi ketika materi tersebut dibahas dan tidak berbisik dengan teman disekitarnya.

Tindakan yang diberikan pada siswa mengenai pemberian brosur bimbingan belajar dan pelaksanaan diskusi kelompok ternyata mampu meningkatkan motivasi belajar pelajaran bahasa Inggris siswa. Adapun peningkatan dari setiap tindakan pada siswa yaitu motivasi belajar pelajaran bahasa Inggris siswa sebelum diberi tindakan yaitu terdapat 6 siswa dari 19 siswa berkategori baik, dengan skor persentase berada diantara 76\% - 100\%. 13 siswa lainnya berada dalam berkategori cukup, dengan skor persentase berada diantara 51\% - 75\%. Hal ini menunjukkan sebagian siswa kurang semangat belajar pelajaran bahasa Inggris sehingga perlu ditingkatkan melalui pelayanan bimbingan dan konseling. Pada awal pelaksanaan tindakan atau siklus I yaitu dengan pemberian dua buah brosur bimbingan belajar dan dua kali mengadakan diskusi kelompok. Siswa mendengarkan materi yang dijelaskan oleh peneliti, namun siswa belum berani memberikan pendapatnya. Setelah pemberian tindakan tersebut motivasi belajar siswa mengalami peningkatan. Motivasi belajar pelajaran bahasa Inggris setelah diberi tindakan (siklus I) diketahui 12 siswa dari 19 siswa berada pada kategori baik, dengan skor persentase berada diantara 76\% - 100\%, sedangkan 7 siswa dari 19 siswa berada dalam ketegori cukup, dengan skor persentase berada diantara 51\% - 75\%. Oleh karena itu, peneliti perlu kembali memberikan tindakan agar seluruh siswa memiliki motivasi belajar pelajaran bahasa Inggris yang baik, dengan skor persentase berada diantara 76\% $100 \%$.

Pelaksanaan siklus II dengan memodifikasi brosur bimbingan belajar yaitu pemberian gambar-gambar serta bentuk huruf teks diganti lebih unik agar siswa lebih tertarik membaca brosur bimbingan belajar yang telah diberikan. Selain itu, peneliti berusaha agar siswa dapat ikut menyumbangkan pendapatnya mengenai topik yang sedang dibahas, misalnya peneliti meminta seluruh siswa dapat memberikan kesimpulan dari diskusi kelompok. Setelah pemberian tindakan pada siklus II, seluruh siswa mengalami peningkatan motivasi belajar pelajaran bahasa Inggris. Motivasi belajar pelajaran bahasa Inggris seluruh siswa atau 19 siswa berada dalam ketegori baik, dengan skor persentase berada diantara 76\% - 100\%. Hal ini menunjukkan tercapainya tujuan penelitian yaitu seluruh siswa mengalami peningkatan motivasi belajar pelajaran bahasa Inggris. Peningkatan rata-rata persentase motivasi belajar pelajaran bahasa Inggris dapat dilihat dalam Tabel 2.

Tabel 2

Persentase Rata-Rata Motivasi Belajar Pelajaran Bahasa Inggris

\begin{tabular}{cccc}
\hline $\begin{array}{c}\text { No. Skor motivasi belajar } \\
\text { siswa SMP }\end{array}$ & $\begin{array}{c}\text { Persentase } \\
\text { rata-rata }\end{array}$ & Kriteria \\
\hline 1. & Pre test & 74,2 & Cukup \\
2. & Post test I & 77,39 & Baik \\
3. & Post test II & 80,66 & Baik \\
\hline
\end{tabular}

Skor skala motivasi belajar yang diperoleh siswa terus mengalami peningkatan karena materi brosur bimbingan belajar menggunakan bahasa yang ringkas dan mudah dipahami. Selain itu, materi yang disusun menggunakan bentuk huruf, warna dan gambar yang menarik. Pelaksanaan diskusi kelompok juga mempengaruhi motivasi belajar siswa, karena dengan diadakan diskusi kelompok siswa menjadi lebih paham mengenai materi brosur bimbingan belajar yang telah diberikan.

Hasil wawancara kepada siswa mengenai kegiatan diskusi kelompok yang telah dilakukan, dapat disimpulkan bahwa mereka senang mengikuti kegiatan diskusi kelompok karena mereka mendapatkan informasi yang berguna bagi dirinya, dapat belajar mengemukakan pendapat di depan teman-temannya, dapat belajar menghargai pendapat antar anggota kelompok. Oleh karena itu, melalui diskusi kelompok siswa dapat memahami materi brosur bimbingan belajar yang telah diberikan. Hasil wawancara kepada 
siswa mengenai brosur bimbingan belajar, dapat disimpulkan pemberian brosur bimbingan belajar tersebut membuat siswa mengerti cara belajar yang baik karena materi brosur bimbingan belajar yang disusun dengan kalimat yang mudah dipahami, pemberian gambar dan warna tulisan yang menarik.

Observasi mengenai motivasi belajar siswa setelah diberi tindakan, menunjukkan siswa merespon materi yang disampaikan pengajar di panti asuhan, mau bertanya jika ada materi yang belum dimengerti, membawa buku materi pelajaran, dan mau mengerjakan tugas yang diberikan. Hal ini berarti siswa semangat mengikuti pembelajaran tentang pelajaran bahasa Inggris.

Dari hasil penelitian, dapat diketahui bahwa media brosur bimbingan belajar dan diskusi kelompok dapat meningkatkan motivasi belajar pelajaran bahasa Inggris siswa SMP di panti asuhan yatim putri 'Aisyiyah Yogyakarta. Hasil penelitian ini telah sesuai dengan tujuan penelitian untuk membantu meningkatkan motivasi belajar pelajaran bahasa Inggris siswa.

\section{Kesimpulan}

Kesimpulan yang dapat dikemukakan dari penelitian ini adalah media brosur bimbingan belajar dan diskusi kelompok dapat meningkatkan motivasi belajar pelajaran bahasa Inggris siswa SMP khususnya di panti asuhan yatim putri 'Aisyiyah Yogyakarta. Hasil penelitian ini dapat digunakan oleh konselor dalam membantu siswa meningkatkan motivasi belajar bahasa Inggris melalui media brosur bimbingan belajar dan diskusi kelompok.

\section{Referensi}

Alwi, H., Sugono, D., Adiwimarta, S. S., Lapowi, Hans., Ruskhan, A. G., Burhanuddin, E., \& Supadi, H. (2002). Kamus Besar Bahasa Indonesia Edisi Ketiga. Jakarta: Balai Pustaka.

Angkowo, R., \& Kosasih, A. (2007). Optimalisasi Media Pembelajaran Mempengaruhi Motivasi, Hasil Belajar dan Kepribadian. Jakarta: Grasindo.

Arikunto, S. (2005). Manajemen Penelitian (Edisi Revisi). Jakarta: Rineka Cipta.

Arikunto, S. (2006). Penelitian Tindakan Kelas. Jakarta: PT. Bumi Aksara.

Arsyad, A. (2002). Media Pembelajaran. Jakarta: RajaGrafindo Persada.

Dimyati \& Mudjiono. (2006). Belajar dan Pembelajaran. Jakarta: Asdi Mahasatya.
Djamarah, S. B. (2008). Psikologi Belajar (Edisi Dua). Jakarta: Rineka Cipta.

Sardiman. (2006). Interaksi dan Motivasi Belajar Mengajar. Jakarta: PT. RajaGrafindo Persada.

Sugiyono. (2009). Metode Penelitian Kuantitatif Kualitatif dan R\&D. Bandung: Alfabeta.

Sukardi, D. K. (2008). Pengantar Pelaksanaan Program Bimbingan dan Konseling di Sekolah. Jakarta: Rineka Cipta.

Sukmadinata, N. S. (2005). Landasan Psikologi Proses Pendidikan. Bandung: PT Remaja Rosdakarya.

Sukmadinata, N. S. (2007). Bimbingan dan Konseling dalam Praktek. Bandung: Maestro.

Suryosubroto, B. (2002). Proses Belajar Mengajar di Sekolah Wawasan Baru, Beberapa Metode Pendukung, dan Beberapa Komponen Layanan Khusus. Jakarta: Rineka Cipta.

Syah, M. (1995). Psikologi Pendidikan dengan Pendekatan Baru. Bandung: PT Remaja Rosdakarya.

Uno, H. B. (2008). Teori Motivasi dan Pengukurannya: Analisis di bidang pendidikan. Jakarta: Bumi Aksara.

Untari, Yusrina Anggraini. (2013). peningkatan hasil belajar IPS siswa kelas v melalui metode simulasi. PSIKOPEDAGOGIA Bimbingan dan Konseling, 2(2): 9-17.

Winkel, W. S., \& Hastuti, M. M. S. (2004). Bimbingan dan Konseling di Institusi Pendidikan (Edisi Revisi). Yogyakarta: Media Abadi.

Yamin, M. (2007). Kiat Membelajarkan Siswa. Jakarta: Gaung Persada Press.

Yusuf, S. \& Nurihsan, A. J. (2006). Landasan Bimbingan dan Konseling. Bandung: Remaja Rosdakarya. 